\title{
Relationships between pelagic bacteria and phytoplankton abundances in contrasting tropical freshwaters
}

\author{
Fábio Roland ${ }^{1, *}$, Lúcia M. Lobão ${ }^{1}$, Luciana O. Vidal ${ }^{1}$, Erik Jeppesen ${ }^{2}$, \\ Rodolfo Paranhos ${ }^{3}$, Vera L. M. Huszar ${ }^{4}$ \\ ${ }^{1}$ Federal University of Juiz de Fora, Laboratory of Aquatic Ecology, Minas Gerais, Brazil, 36036-900 \\ ${ }^{2}$ Dept. of Freshwater Ecology, National Environmental Research Institute, Aarhus University, 8600 Silkeborg, Denmark \\ ${ }^{3}$ Federal University of Rio de Janeiro, Laboratory of Hydrobiology, Rio de Janeiro, Brazil, 21941-901 \\ ${ }^{4}$ Federal University of Rio de Janeiro, Laboratory of Phycology, National Museum, Rio de Janeiro, Brazil, 20940-040
}

\begin{abstract}
While microbial aquatic communities are dominated numerically by viruses, both bacterioplankton and phytoplankton play a basal role in the carbon cycle, producing and mineralizing organic matter and driving $\mathrm{CO}_{2}$ concentrations. Both weak and strong relationships between these 2 microbial groups have been reported for temperate ecosystems. However, data from the tropics and sub-tropics are still scarce, and no consistent pattern regarding the structural microbial connections in these aquatic environments is known so far. We examined bacteria-phytoplankton abundance relationships for tropical freshwaters in comparison to well-studied temperate aquatic ecosystems. We present data on bacterioplankton and phytoplankton abundances in a large data set (1644 samples; lakes, rivers, and reservoirs) from sampling throughout an extensive gradient of latitude $\left(3^{\circ} \mathrm{N}\right.$ to $\left.33^{\circ} \mathrm{S}\right)$ and longitude $\left(35^{\circ}\right.$ to $\left.70^{\circ} \mathrm{W}\right)$ in tropical waters. We found a generally weak, but significant, relationship between bacterioplankton and phytoplankton abundances and between bacterioplankton and chlorophyll. However, analyzing system by system, we observed an increase in the strength of the relationships (expressed by the determination coefficient, $\mathrm{r}^{2}$ ), from 0.05 to 0.17 (bacterioplankton and phytoplankton abundances) and from 0.09 to 0.44 (bacterial abundance and chl a). Our data suggest that the in-system ecological drivers (e.g. water temperature, trophic state, and flushing characteristics, i.e. lentic or lotic) determine the bacterioplankton abundance patterns more than other factors such as latitude or system typology. In a global perspective, the comparison between non-tropical and tropical/sub-tropical freshwaters showed that a lower proportion of phytoplankton carbon is transformed into bacterial carbon in the tropics.
\end{abstract}

KEY WORDS: Microbial dynamics · Bacterial-phytoplankton coupling $\cdot$ Tropical waters

\section{INTRODUCTION}

Pelagic heterotrophic bacteria are extremely important in aquatic ecosystems, with abundance ranges from $<10^{5}$ to $>10^{8}$ cells $\mathrm{ml}^{-1}$ (e.g. Gasol \& Vaqué 1993). Traditionally, the ecological role of heterotrophic bacteria was assumed to be restricted to nutrient mineralization. However, with the acceptance of the microbial-loop concept (Pomeroy 1974, Azam et al. 1983), bacteria were conferred a new ecological role in food webs, representing an alternative route of organicmatter and nutrient transfer to metazoan trophic levels. The microbial loop is an important pathway of energy flow, especially in oligotrophic systems (Roland \& Cole 1999, Biddanda et al. 2001). Bacterial metabolism is supported by both allochthonous and autochthonous dissolved organic matter (DOM). The aquatic food web can be supported by different allochthonous organic carbon sources, but a small fraction of this external dissolved organic carbon (DOC) is transferred to zoo- 
plankton and fish through bacterial biomass (Cole et al. 2006). It is generally believed that autochthonous DOM from phytoplankton is more available for bacterial consumption than allochthonous terrestrial DOC (Kritzberg et al. 2005). Bacteria rapidly assimilate phytoplanktonic carbon compared to terrestrial DOC (Chen \& Wangersky 1996). In tropical freshwaters, for instance, humic substances are an important energy source for aquatic bacteria (Amado et al. 2006), but this source is probably not very relevant as a carbon source for bacterial production, since consumption of humic substances appears to be mostly channeled through microbial respiration (Farjalla et al. 2009).

The dependence of bacterioplankton on autochthonous carbon has been supported by positive relationships between phytoplankton (expressed as chlorophyll a [chl a], cell numbers, or biovolume) and heterotrophic bacteria (expressed as numbers or biomass, Bird \& Kalff 1984, Stewart \& Fritsen 2004; or production, White et al. 1991). A strong relationship is taken as an indication that the growth of bacterioplankton is directly dependent on phytoplankton (Cole et al. 1988, Jeppesen et al. 1997, Gasol \& Duarte 2000). However, this bacterial dependence on phytoplankton has been the focus of recent debate (Lee \& Bong 2008, Sarmento et al. 2008, Stenuite et al. 2009). Recent literature provides support for both strong (Sarmento et al. 2008, Stenuite et al. 2009) and weak dependence (Canosa \& Pinilla 2007, Lee \& Bong 2008) of bacterial growth on phytoplankton activity.

When expressed mathematically as a regression equation between bacteria and algae, the parameters that define the relationships (the slope and the $y$-intercept) can describe important ecological parameters. The slope of the equation between the bacterial and phytoplankton attributes (either abundance or biomass) indicates the proportion of phytoplankton carbon that is transformed into bacterial carbon, while the $y$-intercept estimates the fraction of the bacterial standing stock that appears to be independent of phytoplankton (Currie 1990, Simon et al. 1992, del Giorgio \& Peters 1993).

The strength of the bacterioplankton-phytoplankton relationship varies with the relative importance of autochthonous and allochthonous carbon sources and the nutrient status of the ecosystem. Strong positive relationships are often found in highly productive systems, where the carbon available to bacteria is mainly autochthonous (del Giorgio et al. 1997). However, the proportion of bacterioplankton to phytoplankton biomass tends to be higher in oligotrophic rather than in eutrophic systems, because bacterial biomass increases somewhat more slowly than phytoplankton biomass along a trophic gradient (Cole et al. 1988). In contrast, weak or no relationships have been found in unproductive systems and in systems with high inputs of allochthonous material (Findlay et al. 1991, del Giorgio \& Peters 1994) as allochthonous organic matter can be an alternative energy source for bacteria, decoupling the bacterioplankton-phytoplankton relationship. In this case, bacterial respiration can often exceed phytoplankton production (Karlsson et al. 2002).

It is important to point out that a positive bacterioplankton-phytoplankton relationship does not necessarily indicate bacterial dependence on phytoplankton carbon. In some systems, high inputs of inorganic nutrients (nitrogen and phosphorus) may stimulate the growth of both microbial groups (Currie 1990, Brett et al. 1999). Since, in nutrient-limited conditions, phytoplankton and bacterioplankton compete for nutrients, these relationships may therefore even be negative (Carr et al. 2005).

Predation is another factor that might affect the bacterioplankton-phytoplankton relationship, generally decoupling their dependence (Jeppesen et al. 1997). Bacterial abundance is affected by predation by protozoans and metazoans (Pace et al. 1990) and by viral infection (Fuhrman 1999), with different intensities depending on system type. Grazers control the fate of bacterial communities, and heterotrophic flagellates tend to be the major bacterivores in freshwaters, followed by ciliates, rotifers, and cladocerans (Jürgens \& Jeppesen 2000, Zöllner et al. 2003). Warm lakes are characterized by the dominance of small-bodied zooplankton and higher abundances of rotifers, ciliates, and nanoflagellates, with an elevated grazing impact on bacterioplankton (Crisman \& Beaver 1990, Jeppesen et al. 2007).

The bacterioplankton-phytoplankton relationship has been the focus of a great deal of work (Bird \& Kalff 1984, Cole et al. 1988, Gasol \& Duarte 2000), but the majority of data are from non-tropical aquatic ecosystems. Recent studies have been carried out in tropical regions (Bouvy et al. 1998, Canosa \& Pinilla 2007, Pirlot et al. 2007, Sarmento et al. 2008, Stenuite et al. 2009), but a comprehensive understanding of structural dependency between these aquatic communities is still required. Potentially, the tropics exhibit a large spectrum of types of aquatic ecosystems, especially freshwaters, i.e. running waters and lakes (including shallow, floodplain, and man-made). This heterogeneity among systems is also mixed with a large range of turbidity, DOC, nutrients, and temperature. Here, we investigated bacterial abundance in relation to phytoplankton in tropical waters and evaluated similarities and differences to known patterns derived mainly from temperate systems. A broad survey was conducted in Brazilian lakes, rivers, and reservoirs that vary in trophic state and DOC content. In addition, we com- 
pared our data set to most of the reported available data. We hypothesized that the large impact of the surrounding environment in a tropical climate will force tropical freshwaters to have bacterial abundances weakly correlated with phytoplankton abundances and more related to the geological and hydrodynamic setting of each particular environment.

\section{MATERIALS AND METHODS}

Data sources. Samples were taken between 1999 and 2007 from freshwaters located in Brazil between $04^{\circ} 21^{\prime} 46^{\prime \prime} \mathrm{N}$ and $33^{\circ} 29^{\prime} 53^{\prime \prime} \mathrm{S}$ (Fig. 1). Our data set consisted of a total of 1644 samples, from rivers (890 samples), reservoirs (529), floodplain lakes (131), and coastal lakes (94). All samples were taken in the limnetic zone, below the surface. A single sample was taken from rivers and coastal lakes. The samples, 1 per system from reservoirs, were taken during the prerainy, post-rainy, and dry seasons. One sample for each floodplain lake was taken in different seasons (filling, high water, drawdown, and low water). This procedure allowed us to evaluate the complete hydrologic cycle of this diverse group of environments.

One set of samples (564) was fixed with formalin at a $2 \%$ final concentration for counting the bacteria with an epifluorescence microscope. The remaining set of samples (1080) was fixed with sterile paraformaldehyde at a final concentration of $2 \%$ (Andrade et al. 2003), placed in liquid nitrogen, and stored at $-80^{\circ} \mathrm{C}$ until laboratory analysis by flow cytometry. Phyto-

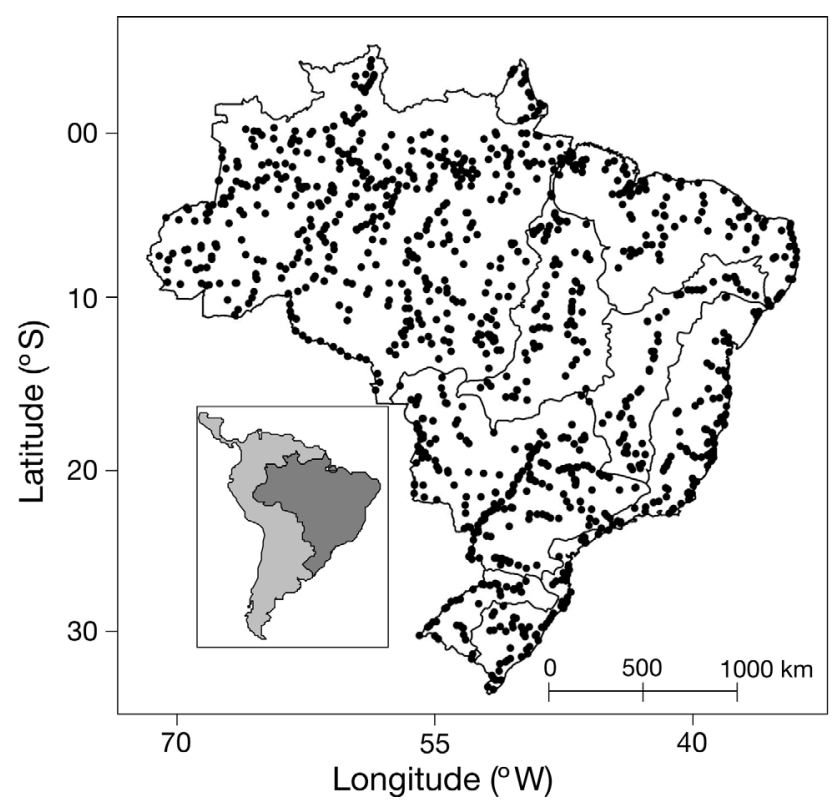

Fig. 1. Brazil, with sampling stations (dots) and major hydrographic regions (solid lines on the map) plankton samples were fixed with Lugol's solution; samples for nutrient analyses and filtered samples for chl a estimates were frozen.

Bacterial abundance $\left(10^{6}\right.$ cells $\left.\mathrm{ml}^{-1}\right)$ was estimated in all samples. Phytoplankton abundance (ind. $\mathrm{ml}^{-1}$ ) was estimated in 1103 samples, and chl a concentrations $\left(\mu \mathrm{g}^{-1}\right)$ in 385 samples. DOC concentrations were obtained from 1487 samples, dissolved inorganic nitrogen (DIN, $\mu \mathrm{g} \mathrm{N} \mathrm{l}^{-1}$ ) from 1384 samples, and soluble reactive phosphorus (SRP) from 1420 samples.

Sample analysis. Bacterioplankton abundance was estimated by direct counts at $1000 \times$ magnification, with an epifluorescence microscope (Olympus BX-60) or by cell counts performed in a CyAn ADP flow cytometer (Dako) equipped with a solid-state laser (488 nm, $24 \mathrm{~mW}$ ) and filter modifications (green fluorescence [FL1] at $510 \pm 15 \mathrm{~nm}$, red fluorescence [FL4] at $650 \pm 10 \mathrm{~nm}$ ). For direct counts, samples (from reservoirs, floodplain lakes, and most coastal lakes) were filtered throughout black polycarbonate filters (0.2 $\mu \mathrm{m}$, Nucleopore $\left.{ }^{\circledR}\right)$ and stained with acridine orange (final concentration, $0.05 \%$; Hobbie et al. 1977), and at least 200 cells were counted. For samples counted by flow cytometry (all river samples and some coastal lakes), abundance was determined after nucleic-acid staining with Syto13 (Molecular Probes) at $2.5 \mu \mathrm{M}$ (del Giorgio et al. 1996). For calibration of side scatter and green fluorescence signals, and as an internal standard for cytometric counts and measurements, fluorescent latex beads (Polysciences, $1.5 \mu \mathrm{m}$ diameter) were systematically added. To validate our mixed bacterial abundance data set, we performed a comparison between the 2 methods. We carried out additional sampling on 20 different systems, including rivers, reservoirs, coastal lakes and floodplain lakes. Bacterial abundances were estimated in these samples using both the epifluorescence (stained with acridine orange) and flow-cytometer techniques. We found a significant relationship between the epifluorescence and flow-cytometer methods $\left(\mathrm{r}^{2}=0.75, \mathrm{p}<\right.$ 0.0001, Fig. 2A), with a slope equal to $1.0( \pm 0.14)$ and $y$-intercept equal to $2 \times 10^{6}$ cell ml $^{-1}\left( \pm 0.51 \times 10^{-6}\right)$. These statistics show a systematic error in the flowcytometer estimates; therefore, all samples counted using flow-cytometry were corrected according to the above regression equation. We also tested the relationship between the acridine orange and DAPI stains, using the epifluorescence procedure. This correlation was also high and significant $\left(\mathrm{r}^{2}=0.93\right.$, $\mathrm{p}<$ 0.0001, Fig. 2B) and showed no biases.

Phytoplankton abundance (ind. $\mathrm{ml}^{-1}$ ) was estimated in random fields, using an inverted microscope (Zeiss Axiovert 10 with plan-neofluor objectives in $400 \times$ magnification) by the sedimentation technique (Utermöhl 1958). We counted all algae we could clearly see, 


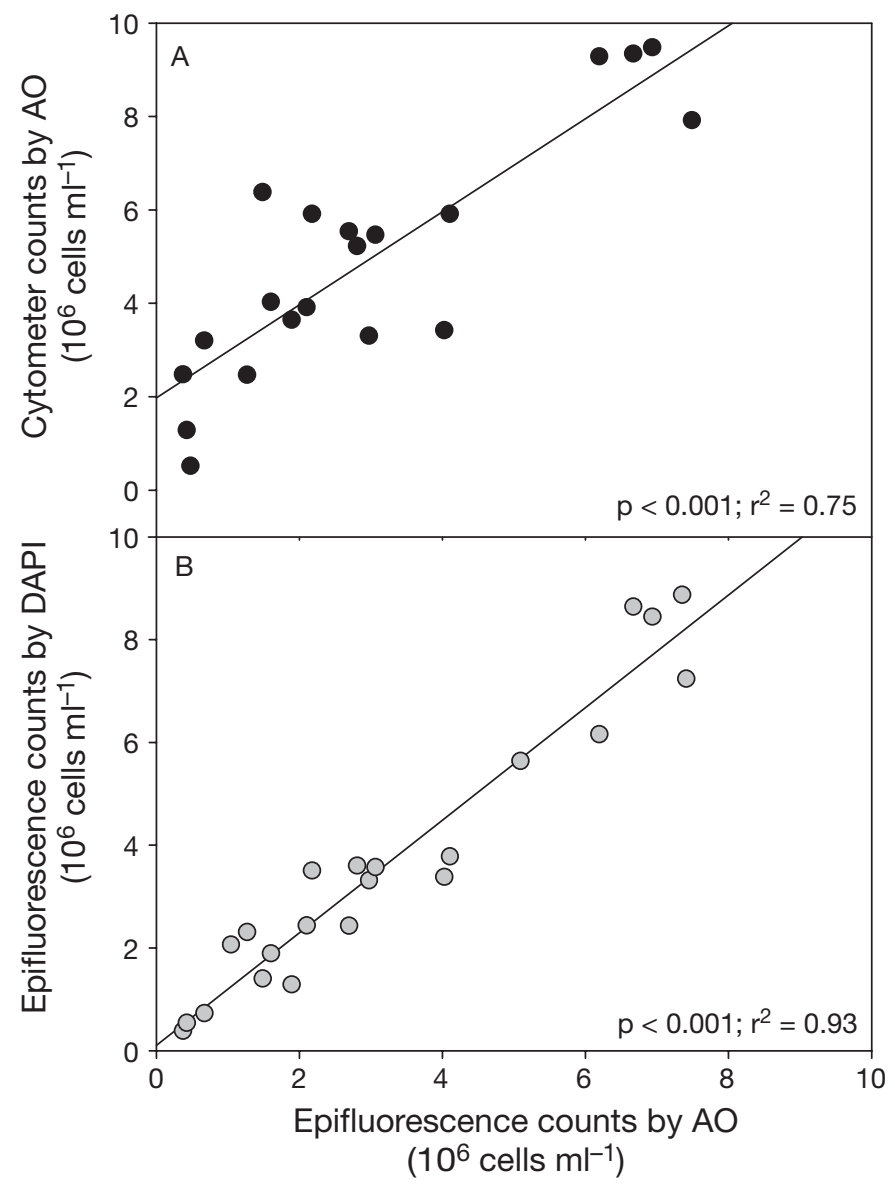

Fig. 2. (A) Bacterioplankton abundance estimated by epifluorescence using acridine orange (AO) vs. cytometer counts and (B) bacterioplankton abundance estimated by epifluorescence using DAPI vs. AO

which ranged in length from $2 \mu \mathrm{m}$ to the largest ones, including all nanoplankton ( 2 to $20 \mu \mathrm{m})$ and microplankton $(20$ to $200 \mu \mathrm{m})$. We followed the Sieburth \& Lenz (1978) classification, which is currently used in most freshwater phytoplankton ecological studies. Sizes $<1$ to $2 \mu \mathrm{m}$, i.e. photosynthetic picoplankton, were not included in our analysis. Chl a was determined using a Turner Designs 450-TD-700 fluorometer; duplicate samples were filtered through Whatman GF/C filters and extracted in $90 \%$ acetone for $24 \mathrm{~h}$ (Wetzel \& Likens 2000). Samples for DOC, DIN, and SRP were filtered through Whatman GF/C filters. DOC was analyzed using a Tekmar-Dhormann Total Carbon Analyzer, model Phoenix 8000, coupled with an auto-sampler. DIN (nitrate, nitrite, and ammonium) and SRP were quantified by spectrophotometry (Wetzel \& Likens 2000) or liquid chromatography through a Dionex ion chromatograph, model DX-80, following APHA (1998). The DOC:DIN and DOC:SRP ratios were calculated on a molar basis.
Data analysis. Data analyses were performed using both the complete data set and by arranging groups according to categories, i.e. systems (rivers, reservoirs, floodplain lakes, and coastal lakes) and trophic state (oligotrophic, mesotrophic, eutrophic, and hypereutrophic). The classification of trophic state was based on Nürnberg (1996), considering total phosphorus and/or chl a concentrations.

We analyzed the relationship between variables by using least-square regressions. All data except temperature were previously $\log _{10}$ transformed to more closely meet the assumption of normality. A $t$-test was used to verify the presence of significant differences among the regression slopes. One-way analysis of variance (ANOVA) and Tukey-Kramer multiple comparison tests were used to test for differences in mean values of bacterioplankton abundance, phytoplankton abundance, chl a, DOC, and DOC:DIN and DOC:SRP ratios across systems. We ran multiple regressions using JMP software (version 5.0.1; SAS Institute); the equations were verified by backward procedures. For all statistical tests, we adopted $p<0.05$ as a threshold level for acceptance.

The comparisons between bacteria and phytoplankton communities in both tropical and non-tropical freshwaters were evaluated using regressions and the raw data (see Table 4). The data from literature were extracted from the graphs using the Matlab Figure Digitizer routine, and standardized for $\log _{10}$ bacterioplankton abundance (cells ml $\left.\mathrm{m}^{-1}\right)$ and $\log _{10} \mathrm{chl} \mathrm{a}\left(\mu \mathrm{gl}^{-1}\right)$. The regression for non-tropical freshwaters was based on the data reported by Gasol \& Duarte (2000), with the addition of the data in all the papers published from 2000 to 2008 .

\section{RESULTS}

\section{Spatial variability}

Phytoplankton abundance, chl $a$, and bacterioplankton abundance varied widely among the systems (Table 1). Bacterioplankton abundances ranged between $10^{4}$ and $10^{8} \mathrm{cells} \mathrm{ml}^{-1}$, with the largest variability in rivers $\left(0.02 \times 10^{6}\right.$ to $\left.94.1 \times 10^{6} \mathrm{cells} \mathrm{m}^{-1}\right)$, although the highest value was found in a reservoir $\left(1.1 \times 10^{8}\right.$ cells $\mathrm{ml}^{-1}$, Fig. 3). Bacterioplankton abundance ranged between $0.06 \times 10^{6}$ and $13.4 \times 10^{6} \mathrm{cells} \mathrm{m}^{-1}$ in floodplain lakes, and $0.02 \times 10^{6}$ and $23.4 \times 10^{6} \mathrm{cells} \mathrm{ml}^{-1}$ in coastal lakes. In the entire data set, phytoplankton (excluding picoplankton) abundance ranged between 10 and $10^{5}$ ind. $\mathrm{ml}^{-1}$, ranging from $0.01 \times 10^{3}$ to $106.7 \times 10^{3}$ ind. $\mathrm{ml}^{-1}$ in reservoirs; $0.01 \times 10^{3}$ to $132 \times 10^{3}$ ind. $\mathrm{ml}^{-1}$ in rivers; and $0.09 \times 10^{3}$ to $25.4 \times 10^{3}$ ind. $\mathrm{ml}^{-1}$ in floodplain lakes; the highest values were generally found in 
Table 1. Median, mean, and standard error (SE) of bacterioplankton $\left(10^{6}\right.$ cells $\left.\mathrm{ml}^{-1}\right)$ and phytoplankton abundances $\left(10^{3}\right.$ ind. $\mathrm{ml}^{-1}$; not including picoplankton: see 'Materials

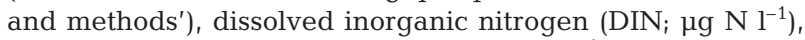

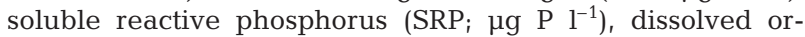
ganic carbon (DOC; $\left.\mathrm{mg} \mathrm{C}^{-1}\right)$, chl a concentrations $\left(\mu \mathrm{g} \mathrm{l}^{-1}\right)$, and DOC:DIN and DOC:SRP ratios (molar) in Brazilian ecosystems

\begin{tabular}{|lcccc|}
\hline & Median & Mean & SE & N \\
\hline Bacterioplankton abundance & 0.9 & 2.8 & 3.0 & 847 \\
Phytoplankton abundance & 1.5 & 6.4 & 2.5 & 1117 \\
DIN & 118.5 & 207.2 & 2.1 & 1511 \\
SRP & 3.1 & 10.9 & 5.8 & 1418 \\
DOC & 3.0 & 4.7 & 1.2 & 1472 \\
Chl $a$ & 3.7 & 9.4 & 3.6 & 398 \\
DOC:DIN & 10.9 & 87.7 & 3.0 & 1472 \\
DOC:SRP & 240.1 & 744.9 & 1.9 & 1147 \\
\hline
\end{tabular}

coastal lakes $\left(0.1 \times 10^{3}\right.$ to $148.9 \times 10^{3}$ ind. $\left.\mathrm{ml}^{-1}\right)$. As observed for phytoplankton abundance, higher chl a concentrations were found in coastal lakes $(0.7$ to $437.6 \mu \mathrm{g}$ $\mathrm{l}^{-1}$ ). The range in reservoirs varied from 0.1 to $34.8 \mu \mathrm{g}$ $\mathrm{l}^{-1}$, and in floodplain lakes from 0.5 to $76.0 \mathrm{\mu g} \mathrm{l}^{-1}$.

Nutrient concentrations (carbon, nitrogen, and phosphorus) varied widely among and within systems (Fig. 3, Table 1). DIN concentration ranged from 0.02 (rivers) to $6645.5 \mu \mathrm{g} \mathrm{N}^{-1}$ (reservoirs), and SRP concen-

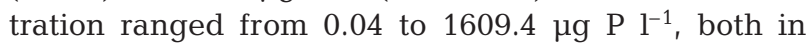
reservoirs. A lower variability was found in DOC concentrations, which ranged between 0.01 and $64.6 \mathrm{mg} \mathrm{C}$ $\mathrm{l}^{-1}$ both in rivers. The wide range is caused by a few extreme values (mean $4.9 \pm 5.9 \mathrm{mg} \mathrm{C} \mathrm{l}^{-1}$, Table 1, Fig. 3). DOC:DIN and DOC:SRP ratios also varied widely (0.2 to 3307 and 7.4 to 13813 , respectively). Except for phytoplankton abundance, all other data in Fig. 3 show that reservoirs were the systems where significantly (ANOVA, p < 0.05) lower values were found. Rivers were the systems with the lowest phytoplankton abundances.

\section{Regression analyses}

By pooling all data, a weak but significant relationship was found between bacterioplankton abundance (BA) and phytoplankton abundance (PA; Eq. 1, Fig. 4). The same scenario was also observed for the relationship between bacterioplankton abundance and phytoplankton biomass, expressed as chl a (Eq. 2, Fig. 4):

$$
\begin{gathered}
\log \mathrm{BA}=0.15( \pm 0.03) \times \log \mathrm{PA}+5.49( \pm 0.09) \\
\left(\mathrm{r}^{2}=0.05 ; \mathrm{n}=643, \mathrm{p}<0.0001\right) \\
\log \mathrm{BA}=0.28( \pm 0.05) \times \log \mathrm{Chl} a+5.68(0.04) \\
\left(\mathrm{r}^{2}=0.09, \mathrm{n}=383, \mathrm{p}<0.0001\right)
\end{gathered}
$$

The slopes of Eqs. (1) and (2) were significantly different ( $t$-test, $\mathrm{p}<0.05$ ), being higher for bacterioplankton abundance versus chl a. Compared to other studies, also based on large data sets (e.g. Gasol \& Duarte 2000), the slopes of our equations were significantly lower (covariance analysis, p < 0.05; Fig. 5).

Significant relationships between bacterioplankton and phytoplankton abundances were found when the different types of systems were analyzed separately, but these relationships were still weak (Table 2, Fig. 4). The bacterioplankton-phytoplankton abundance relationships were weakly positive in reservoirs and floodplain lakes, whereas no relationship was found for coastal lakes and rivers. The steepest slopes were observed for floodplain lakes (0.27 \pm $0.12)$ and reservoirs $(0.22 \pm 0.03)$. Bacterioplankton abundance was also positively related to chl a in reservoirs and floodplain lakes, and no relationship was found for coastal lakes (Table 2, Fig. 4). For the relationship between chl $a$ and bacterioplankton abundance, the slopes were again steepest for floodplain lakes $(0.82 \pm 0.16)$, and much lower for reservoirs $(0.31 \pm 0.08)$.

The subdivision by trophic state revealed more robust bacterioplankton-phytoplankton abundance relationships (Table 2). Relatively strong negative regressions were found for mesotrophic and oligotrophic coastal lakes, whereas positive relationships were found for eutrophic reservoirs and eutrophic coastal lakes. Weak positive relationships were found for mesotrophic and oligotrophic reservoirs and hypertrophic coastal lakes, and for eutrophic rivers (Table 2). Thus, the strongest positive relationships were recorded in lentic, relatively enriched systems such as eutrophic reservoirs and coastal lakes. Comparing the slopes showed that the potential utilization of phytoplankton carbon by bacterioplankton was significantly higher in floodplain lakes than in reservoirs, whereas no significant relationship was identified for rivers and coastal lakes (Table 2, Fig. 4).

\section{Influences of inorganic nutrients, dissolved organic carbon and temperature}

By including SRP, DIN, DOC, and temperature in a multiple regression, improvements in several relationships were obtained (Table 3). For the entire data set, temperature and DOC contributed positively, and SRP negatively, to the relationship between bacterioplankton and phytoplankton abundance or chl a. DIN also contributed positively to bacterioplankton and phytoplankton abundance relationships in reservoirs. The extended equations accounted for 25 and $34 \%$ of the variation in bacterioplankton abundance (Table 3 ). 

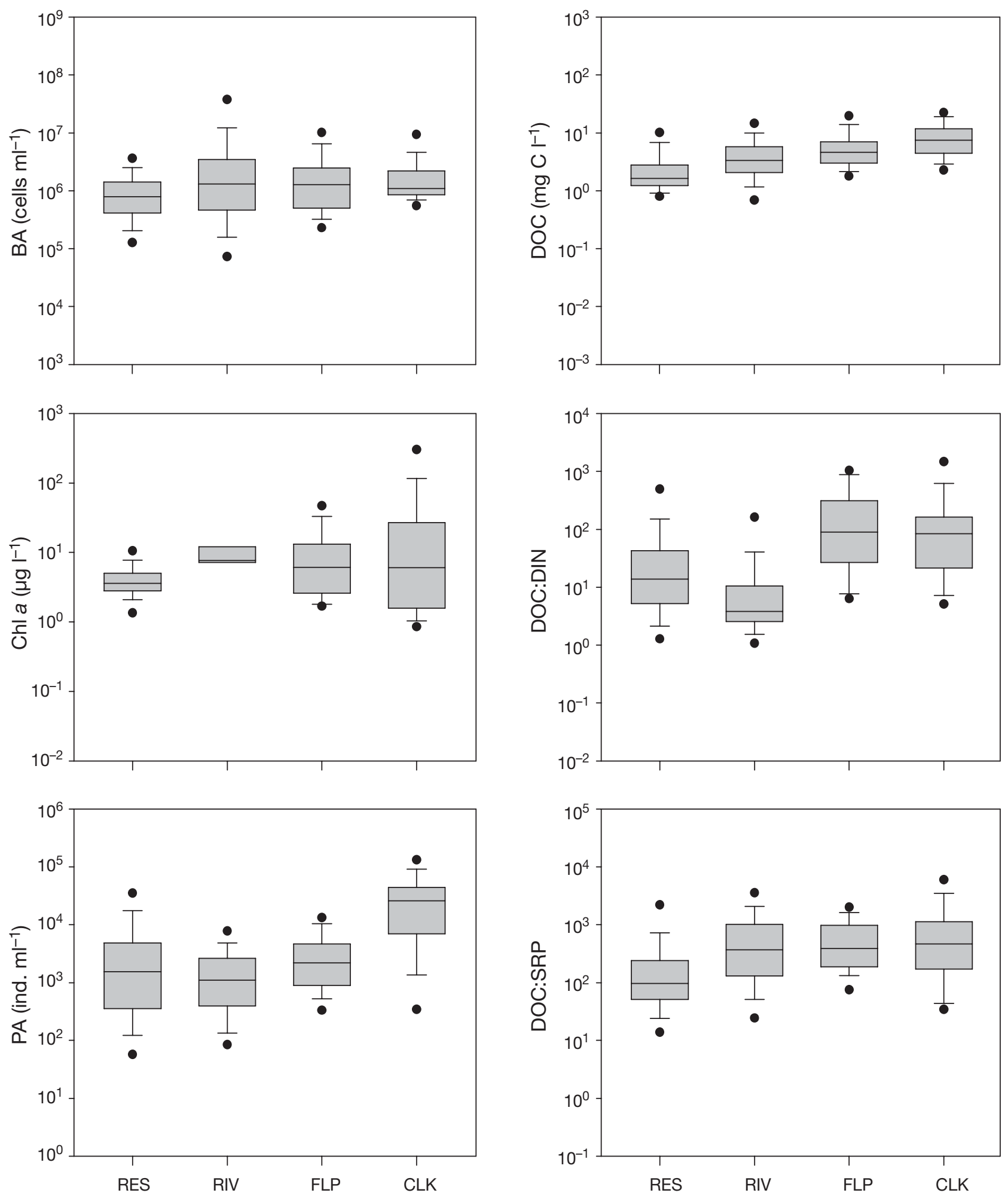

Fig. 3. Bacterioplankton abundance (BA), phytoplankton abundance (PA), chlorophyll a (chl a), dissolved organic carbon (DOC), DOC: dissolved inorganic nitrogen (DIN) ratios, and DOC:soluble reactive phosphorus (SRP) ratios in Brazilian reservoirs (RES), rivers (RIV), floodplain lakes (FLP), and coastal lakes (CLK). All data were $\log _{10}$ transformed. Variation in a given type of system is expressed by a box whisker plot, in which the line within boxes is the median and the boundary of the box farthest from 0 indicates the 75th percentile. Whiskers (error bars) encompass the 90th and 10th percentiles and dots ( $\bullet$ ) represent outliers in the range from the 5 th to 10 th and 90th to 95th percentiles 

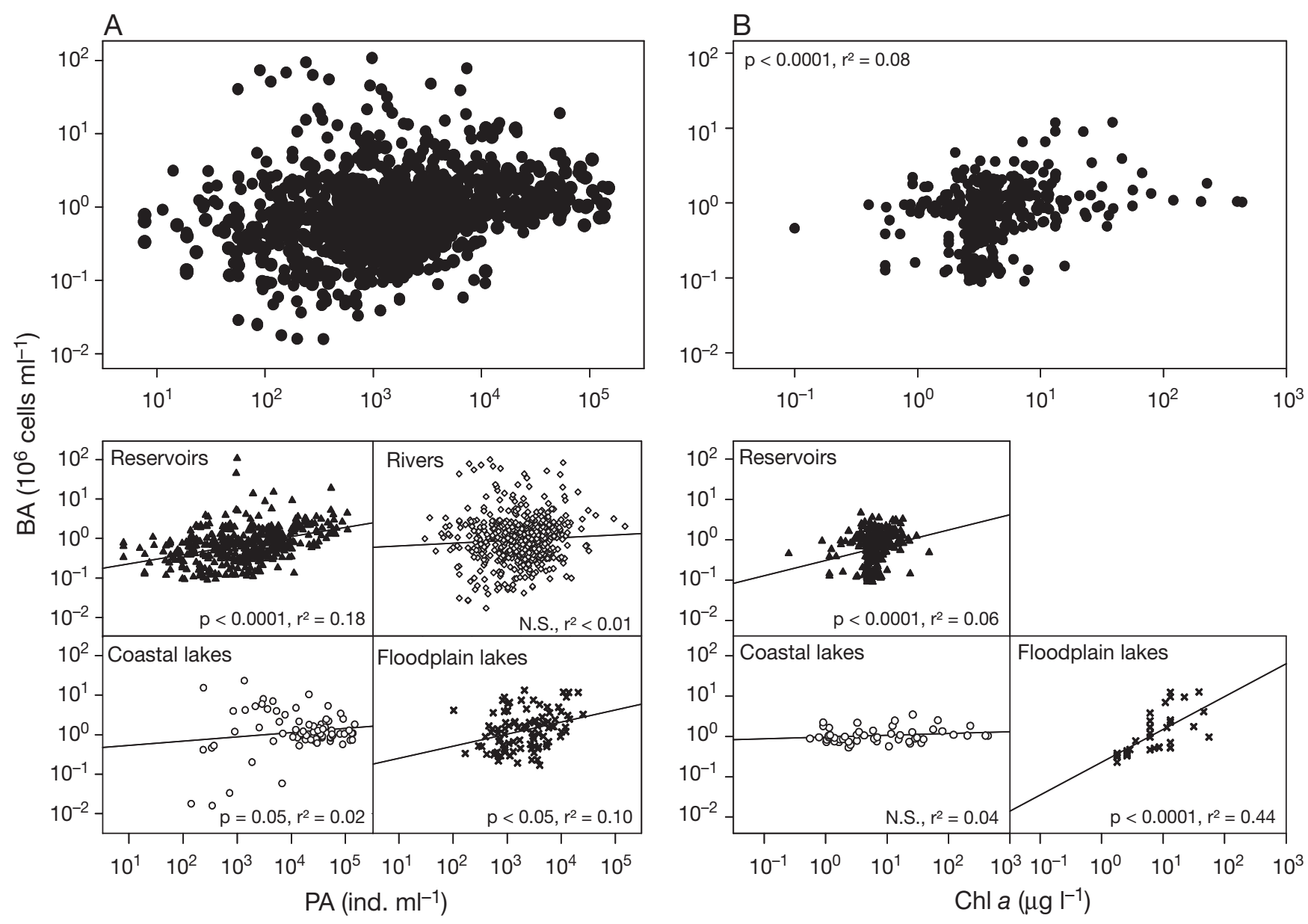

Fig. 4. (A) Bacterioplankton abundance (BA) vs. phytoplankton abundance (PA) and (B) BA vs. chl a. All data are shown in the upper panels, and data are divided into system type (reservoirs, rivers, floodplain lakes, coastal lakes) in the lower panels.

Phytoplankton abundances do not include picophytoplankton

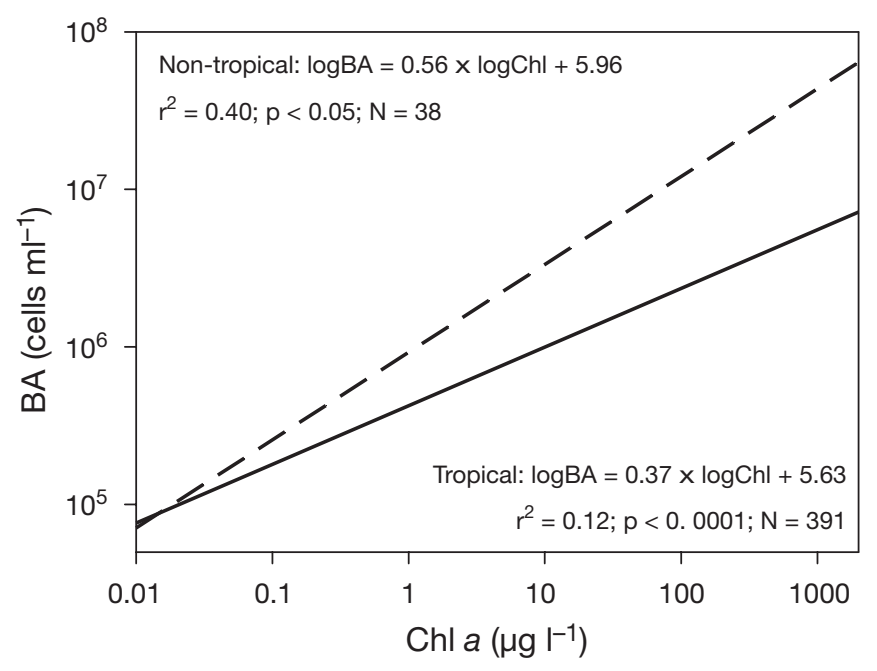

Fig. 5. Relationships between bacterioplankton abundance (BA) and chl a for non-tropical freshwaters (dashed line) and for tropical freshwaters (solid line)
In rivers, bacterioplankton abundance was positively related to phytoplankton abundance and DOC, and negatively to DIN in floodplain lakes.

\section{Comparison to temperate lakes}

Using literature data, a strong positive relationship was obtained between bacterioplankton abundance and phytoplankton (as chl a) in non-tropical lakes (Fig. 5). Except in floodplain lakes and reservoirs, the percentage of variability in bacterial abundance explained by phytoplankton in our equations was lower than that explained in temperate systems (Table 4). For floodplain (Zinabu \& Taylor 1997, Canosa \& Pinilla 2007) and coastal lakes (Gocke et al. 2004), however, some studies found phytoplankton to explain similar fractions of the variability to those found in the present study. 
Table 2. Regressions describing $\log _{10}$ bacterioplankton abundance (BA, cells $\mathrm{ml}^{-1}$ ) and $\log _{10}$ phytoplankton abundance (PA, $10^{3}$ ind. $\mathrm{ml}^{-1}$; not including picoplankton; see 'Materials and methods'), and $\log _{10} \mathrm{BA}$ and $\log _{10}$ chl a ( $\mu \mathrm{g} \mathrm{l}^{-1}$ ) in Brazilian freshwaters according system types and trophic states (oligo: oligotrophic, meso: mesotrophic, eutro: eutrophic, hyper: hypereutrophic). Standard errors (SE) are given in parentheses. ${ }^{*} \mathrm{p}<0.05$ ( $t$-test). - : no data

\begin{tabular}{|c|c|c|c|c|c|c|c|c|c|}
\hline \multirow{2}{*}{$\begin{array}{c}\text { System } \\
\text { types }\end{array}$} & \multirow{2}{*}{$\begin{array}{c}\text { Trophic } \\
\text { states }\end{array}$} & \multicolumn{2}{|c|}{- Intercept -} & \multicolumn{2}{|c|}{ Slope -} & \multicolumn{2}{|c|}{$\mathrm{r}^{2}$} & \multirow[b]{2}{*}{$\mathrm{BA} \times \mathrm{PA}$} & \multirow{2}{*}{$\mathrm{N}$} \\
\hline & & $\mathrm{BA} \times \mathrm{PA}$ & $\mathrm{BA} \times \operatorname{chl} a$ & $\mathrm{BA} \times \mathrm{PA}$ & $\mathrm{BA} \times \operatorname{chl} a$ & $\mathrm{BA} \times \mathrm{PA}$ & $\mathrm{BA} \times \operatorname{chl} a$ & & \\
\hline \multirow[t]{5}{*}{ Reservoirs } & All & $5.2(0.08)^{*}$ & $5.6(0.05)^{*}$ & $0.2(0.02)^{*}$ & $0.3(0.08)^{*}$ & $0.17^{*}$ & $0.05^{*}$ & 379 & 298 \\
\hline & Oligo & $6.1(2.8)$ & - & $0.2(0.8)$ & - & 0.01 & - & 5 & - \\
\hline & Meso & $5.3(0.08)^{*}$ & $5.6(0.05)^{*}$ & $0.2(0.02)^{*}$ & $0.3(0.08)$ & $0.11^{*}$ & $0.05^{*}$ & 345 & 298 \\
\hline & Eutro & $6.1(0.5)^{*}$ & - & $0.06(0.1)^{*}$ & - & 0.01 & - & 28 & - \\
\hline & Hyper & - & - & - & - & - & - & - & - \\
\hline \multirow[t]{5}{*}{ Rivers } & All & $6.3(0.4)^{*}$ & - & $0.05(0.04)$ & - & $<0.01$ & - & 119 & - \\
\hline & Oligo & $6.2(0.6)^{*}$ & - & $0.1(0.2)$ & - & $<0.01$ & - & 49 & - \\
\hline & Meso & $6.7(0.7)$ & - & $0.1(0.2)$ & - & $<0.01$ & - & 40 & - \\
\hline & Eutro & $5.8(0.6)^{*}$ & - & $0.2(0.2)$ & - & 0.03 & - & 27 & - \\
\hline & Hyper & - & - & - & - & - & - & 9 & - \\
\hline \multirow{5}{*}{$\begin{array}{l}\text { Floodplain } \\
\text { lakes }\end{array}$} & All & $5.2(0.4)^{*}$ & $5.4(0.2)^{*}$ & $0.3(0.1)^{*}$ & $0.8(0.2)^{*}$ & $0.10^{*}$ & $0.44^{*}$ & 78 & 34 \\
\hline & Oligo & - & - & - & - & - & - & & - \\
\hline & Meso & $4.9(0.4)^{*}$ & $5.3(0.2)^{*}$ & $0.3(0.1)^{*}$ & $0.8(0.2)^{*}$ & $0.10^{*}$ & $0.44^{*}$ & 74 & 34 \\
\hline & Eutro & $6.3(2.5)$ & - & $0.2(0.3)$ & - & -0.05 & - & 3 & - \\
\hline & Hyper & - & - & - & - & - & - & - & - \\
\hline \multirow{5}{*}{$\begin{array}{c}\text { Coastal } \\
\text { lakes }\end{array}$} & All & $7.4(0.3)^{*}$ & $5.9(0.04)^{*}$ & $0.3(0.07)^{*}$ & $0.04(0.03)$ & $-0.20^{*}$ & 0.04 & 67 & 50 \\
\hline & Oligo & $8.6(1.0)^{*}$ & - & $0.5(0.3)$ & - & -0.61 & - & 8 & - \\
\hline & Meso & $7.7(0.6)^{*}$ & $5.9(0.09)^{*}$ & $0.4(0.2)^{*}$ & $0.07(0.14)$ & $-0.32^{*}$ & 0.03 & 16 & 9 \\
\hline & Eutro & $6.5(0.6)^{*}$ & $5.9(0.04)^{*}$ & $0.1(0.1)^{*}$ & $0.04(0.05)$ & $0.02^{*}$ & -0.02 & 30 & 26 \\
\hline & Hyper & $5.4(0.7)^{*}$ & $6.5(0.1)^{*}$ & $0.2(0.2)$ & $0.01(0.07)$ & 0.06 & $<0.01$ & 17 & 15 \\
\hline
\end{tabular}

Table 3. Multiple regressions of $\log _{10}$ bacterioplankton abundance (cells $\mathrm{ml}^{-1}$ ) vs. (A) $\log _{10}$ phytoplankton abundance (PA,

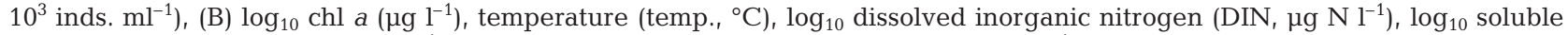

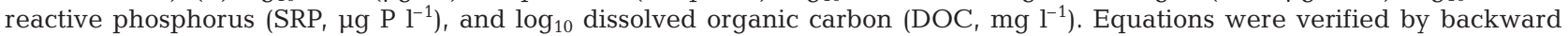
procedures. Standard errors (SE) are given in parentheses. Significance level $\mathrm{p}<0.05$, standard F-test. Blank cells: no significant relationship ( $\mathrm{p}>0.05)$

\begin{tabular}{|c|c|c|c|c|c|c|c|c|c|c|}
\hline System & & Intercept & $r^{2}$ & Chl a & PA & Temp. & DIN & SRP & DOC & $\mathrm{N}$ \\
\hline \multirow{2}{*}{ All systems } & A & $4.8(0.3)$ & 0.16 & & \multirow{2}{*}{$0.01(0.02)$} & $0.03(0.009)$ & & $-0.13(0.05)$ & $0.4(0.07)$ & 427 \\
\hline & B & $4.3(0.2)$ & 0.29 & $0.2(0.05)$ & & $0.05(0.007)$ & & $-0.10(0.03)$ & $0.15(0.05)$ & 284 \\
\hline \multirow{2}{*}{ Reservoir } & A & $3.7(0.3)$ & 0.24 & & \multirow[t]{2}{*}{$0.1(0.03)$} & $0.06(0.008)$ & $0.2(0.04)$ & \multirow{3}{*}{$\begin{array}{l}-0.2(0.03) \\
-0.1(0.03)\end{array}$} & & 276 \\
\hline & B & $3.6(0.3)$ & 0.31 & $0.2(0.08)$ & & $0.07(0.007)$ & $0.2(0.06)$ & & & 234 \\
\hline River & $\mathrm{A}$ & $5.8(0.4)$ & 0.04 & & $0.01(0.1)$ & & $0.1(0.1)$ & & & 116 \\
\hline Floodplain & $\mathrm{A}$ & $6.6(0.9)$ & 0.33 & & $0.2(0.3)$ & & $-0.9(0.4)$ & $1.9(0.9)$ & & 16 \\
\hline
\end{tabular}

\section{DISCUSSION}

The relationship between bacterioplankton and phytoplankton, as well as its driving factors, is well established for temperate systems (Bird \& Kalff 1984, Cole et al. 1988, Gasol \& Duarte 2000), but not for tropical ones. A general weak relationship was observed in our study of 1141 freshwater Brazilian aquatic ecosystems. Moreover, by dividing the data set into rivers, reservoirs, and coastal lakes, we found positive but still weak relationships compared to those reported by studies in other freshwater and saltwater systems (Cole et al. 1988, White et al. 1991). Similarly to previous observations (Naganuma 1997, Biddanda et al. 2001, Shiah et al. 2001), a wide variation in the relationship between bacterioplankton and phytoplankton was found in this study. This variation was dependent on the particular type and on the trophic state of the freshwater systems.

The first studies treating the relationship between bacterioplankton and phytoplankton showed an influence of limiting nutrients on these interactions (Currie 1990). However, considering all systems, no strong evidence of the influence of inorganic nutrients was observed in our dataset. The inclusion of SRP in the multiple regression analysis improved the bacterioplankton-phytoplankton relationship only for reservoirs and floodplain lakes. In a recent experimental approach in 2 lakes located in Minnesota, USA, Stets \& 
Table 4. Literature review of regressions between bacterioplankton abundance (BA) and phytoplankton abundance (PA) or chl a in aquatic ecosystems throughout the world. All values were log-transformed to compare regression statistics. Bacterioplankton abundance is $\log _{10}\left(\right.$ cells $\left.\mathrm{ml}^{-1}\right)$, chl $a$ is $\log _{10}\left(\mu \mathrm{g} \mathrm{l} \mathrm{l}^{-1}\right)$, and phytoplankton abundance is $\log _{10}\left(10^{3}\right.$ ind. $\left.\mathrm{ml}^{-1}\right)$

\begin{tabular}{|c|c|c|c|c|c|c|c|}
\hline Locations & $\mathrm{r}^{2}$ & Intercept & Slope & Chl a & Variables & $\mathrm{N}$ & Source \\
\hline \multicolumn{8}{|l|}{ Non-tropical regions } \\
\hline Minnesota lake (USA) & 0.56 & 6.40 & 0.33 & $0.5-53$ & $\operatorname{logBA}$ vs. $\log C h l a$ & 12 & Biddanda et al. (2001) \\
\hline Danish lakes & 0.12 & 6.58 & 0.16 & $2.0-121$ & $\operatorname{logBA}$ vs. $\log C h l a$ & 16 & Søndergaard \& Danielsen (2001) \\
\hline North America (USA) & 0.41 & 6.13 & 0.27 & $1.9-55.6$ & $\operatorname{logBA}$ vs. $\log C h l a$ & 19 & Kritzberg et al. (2005) \\
\hline Canadian lakes & 0.10 & 6.05 & 0.33 & $1.9-7.8$ & $\operatorname{logBA}$ vs. $\log C h l a$ & 9 & Tadonléké et al. (2004) \\
\hline Danish lakes & 0.88 & 5.68 & 1.71 & $0.8-1.7$ & $\operatorname{logBA}$ vs. $\log C h l a$ & 5 & Christoffersen et al. (2002) \\
\hline Hudson River (USA) & 0.11 & 6.80 & 0.21 & 11 (mean) & $\operatorname{logBA}$ vs. $\log C h l a$ & 146 & Findlay et al. (1991) \\
\hline North American rivers (USA) & 0.54 & 6.60 & 0.70 & $0.0-13$ & $\operatorname{logBA}$ vs. $\log C h l a$ & 20 & Gao et al. (2004) \\
\hline Review & 0.55 & 5.94 & 0.47 & $0.2-0.8$ & $\operatorname{logBA}$ vs. $\log C h l a$ & 33 & Gasol \& Duarte (2000) \\
\hline \multicolumn{8}{|l|}{ Tropical and subtropical regions } \\
\hline Andes (Colombia) & 0.20 & 3.90 & 0.30 & $0.01-16$ & $\log \mathrm{BA}$ vs. $\log \mathrm{PA}$ & 27 & Canosa \& Pinilla (2007) \\
\hline Ethiopian lakes & 0.57 & 7.12 & 0.16 & $1.4-616$ & $\operatorname{logBA}$ vs. $\log C h l a$ & 57 & Zinabu \& Taylor (1997) \\
\hline Ivory Coast reservoir & 0.63 & 8.80 & 0.58 & $5.9-59$ & $\operatorname{logBA}$ vs. $\log \mathrm{Chl} a$ & 93 & Bouvy et al. (1998) \\
\hline Lagoon de Ciénaga (Colombia) & 0.03 & 7.58 & 0.11 & $6.0-182$ & $\log B A$ vs. $\log C h l a$ & 93 & Gocke et al. (2004) \\
\hline Peninsular Malaysia & 0.18 & 6.06 & 0.41 & $2.0-3.8$ & $\log B A$ vs. $\log C h l a$ & 45 & Lee \& Bong (2008) \\
\hline Brazilian reservoirs & 0.05 & 5.60 & 0.34 & $0.1-35$ & $\operatorname{logBA}$ vs. $\log C h l a$ & 298 & Present study \\
\hline Brazilian reservoirs & 0.17 & 6.10 & 0.23 & $0.1-35$ & $\log \mathrm{BA}$ vs. $\log \mathrm{PA}$ & 345 & Present study \\
\hline Brazilian rivers & $<0.01$ & 6.30 & 0.05 & $7.9-14$ & $\log \mathrm{BA}$ vs. $\log \mathrm{PA}$ & 119 & Present study \\
\hline Brazilian floodplain lakes & 0.44 & 5.40 & 0.81 & $0.7-56$ & $\operatorname{logBA}$ vs. $\log C h l a$ & 34 & Present study \\
\hline Brazilian floodplain lakes & 0.10 & 5.20 & 0.31 & $0.7-56$ & $\log \mathrm{BA}$ vs. $\log \mathrm{PA}$ & 78 & Present study \\
\hline South American coastal lakes & 0.04 & 5.90 & 0.04 & $0.6-438$ & $\operatorname{logBA}$ vs. $\log C h l a$ & 54 & Present study \\
\hline South American coastal lakes & -0.20 & 7.40 & 0.30 & $0.6-438$ & $\log \mathrm{BA}$ vs. $\log \mathrm{PA}$ & 67 & Present study \\
\hline
\end{tabular}

Cotner (2008) demonstrated the control of the bacterioplankton-phytoplankton relationship by inorganic phosphorus along a gradient of carbon concentrations. In contrast to the results of Stets \& Cotner (2008), our findings indicate that carbon is also an important factor for the relationship in all systems, except in floodplain lakes. Carbon quality affects bacterial metabolism in tropical systems (Farjalla et al. 2009), and a high C:N:P ratio (in the forms of DOC:DIN:SRP) indicates low carbon quality. The C:N:P ratios (molar) in our study were high (240:10:1) compared to ratios in other aquatic systems and bacteria cultures (50:10:1, Fagerbakke et al. 1996).

The relationships that we found were weak, even after we included nutrients, temperature, and DOC in the analyses. Although zooplankton was not considered in the present study, it is important to recognize the grazers' effects on the relationship between bacterioplankton and phytoplankton in tropical waters. Predation is somewhat different in temperate and tropical freshwaters. Likely because of high fish predation, warm lakes are dominated by small-bodied zooplankton (Jeppesen et al. 2007, Meerhoff et al. 2007), leading to higher abundances of rotifers, ciliates (Crisman \& Beaver 1990), and nanoflagellates (Jeppesen et al. 1996). Rapid turnover and low bacterioplankton-chl a ratios are therefore expected in warm lakes, although bacterioplankton production can be high.
The variability in the relationships between bacterioplankton and phytoplankton among types of systems indicates that weak relationships can be explained by different in-system factors. In Brazilian coastal lakes, for example, trophic state is an important factor driving phytoplankton composition and production (Roland 1998). The lack of a relationship between bacterial abundance and chl $a$ in oligo- and mesotrophic coastal lakes could be related to the incomplete retention of all size classes by the filter used in the chl a analysis. In floodplain lakes, however, chl a was strongly related to bacterial abundance, caused by the high phytoplankton biomass in these systems, especially during lowwater periods (Huszar \& Reynolds 1997, Nabout et al. 2006). The high phytoplankton biomass could imply high amounts of phytoplankton carbon in those systems, which is the major carbon source for the bacterioplankton, and therefore the relationship between the 2 groups could be stronger. Hence, the hydrological regime is an important factor driving the relationship between bacterioplankton and phytoplankton in floodplain lakes. As expected, weak relationships were found in rivers, which have low phytoplankton biomass with high production only in low-flow and lowturbidity phases (Reynolds 1995, Soares et al. 2007). A weak relationship between bacteria and phytoplankton was also found in our reservoirs, probably due to the low chl a concentrations. Low phytoplankton bio- 
mass has previously been reported for some Brazilian reservoirs, and was explained as a consequence of short retention time (Pivato et al. 2006).

Most of our equations showed coefficients of determination lower than those found in temperate systems (Table 4). In some cases, our coefficients were even lower than those found in other tropical systems (Zinabu \& Taylor 1997, Bouvy et al. 1998, Sarmento et al. 2008, Stenuite et al. 2009). The weaker relationships compared to other studies are probably related to the high heterogeneity of systems included in the present study, while most of the literature information is based on studies that include less heterogeneity among systems.

The slope of the equation between phytoplankton and bacteria can be used to estimate the proportion of phytoplankton carbon assimilated by bacterioplankton (Currie 1990, del Giorgio \& Peters 1993), and the $y$ intercept has been used to indicate the proportion of total bacterial abundance that would be independent of phytoplankton biomass (Simon et al. 1992). In comparison to temperate freshwaters, the lower values for the slopes found in tropical freshwaters (e.g. Sarmento et al. 2008, Table 4) suggest a small fraction of bacterial abundance supported by phytoplankton.

In synthesis, weak relationships between bacterioplankton and phytoplankton were observed in the combined data set, covering a large number of Brazilian freshwaters. However, analyzing system by system we observed an increase in the relationships, expressed by the determination coefficient $\left(\mathrm{r}^{2}\right)$, between bacterioplankton and phytoplankton. The variation in the relationships in rivers, reservoirs, floodplain lakes, and coastal lakes, when analyzed separately, suggest that drivers of the weak relationship between bacteria and phytoplankton are different for each type of system. We also found that by adding SRP, DOC, and temperature in a multiple regression approach, many of the relationships showed higher $\mathrm{r}^{2}$, although still remained weak. Based on the values of the $y$-intercept, our data also indicate that a lower fraction of bacteria is supported by phytoplankton abundance in tropical freshwaters, as compared to other ecosystems worldwide. The weak bacterioplankton-phytoplankton relationships found in the present study reflect the power of in-system ecological drivers. Temperature, trophic states, and flushing characteristics (lentic or lotic) might be important constraints to the patterns of relationship between the 2 groups of organisms in tropical freshwaters.

Acknowledgements. We thank M. Scheffer and N. Mazzeo for South America Lake Gradient Analysis (SALGA) data, and G. Moss, D. Abe, and J. G. Tundisi for Brasil das Águas Project (BDA) data. We are grateful to A. Mette (Aarhus University) and J. W. Reid (JWR Associates) for revising the English and A. P. O. Nuñer for statistical support. We thank A. M. Amado and R. F. Mendonça for useful suggestions. This study was supported by FURNAS Centrais Elétricas S.A, Brazil, and Conselho Nacional de Desenvolvimento Científico e Tecnológico (CNPq), Brazil (fellowships to F.R., R.P., and V.L.M.H.). E.J. was supported by EUROLIMPACS (GOCECT-2003-505540) and The Research Council for Nature and Universe (272-08-0406). This is a contribution of the Laboratory of Aquatic Ecology, University of Juiz de Fora, Brazil.

\section{LITERATURE CITED}

Amado AM, Farjalla VF, Esteves FA, Bozelli RL, Roland F, Enrich-Prast A (2006) Complementary pathways of dissolved organic carbon removal pathways in clear-water Amazonian ecosystems: photochemical degradation and bacterial uptake. FEMS Microbiol Ecol 56:8-17

Andrade L, Gonzalez AM, Araujo FV, Paranhos R (2003) Flow cytometry assessment of bacterioplankton in tropical marine environments. J Microbiol Methods 19:89-94

APHA (American Public Health Association) (1998) Standard methods for the examination of water and wastewater. In: Clescerl LS, Greenberg AE, Eaton AD (eds) Book 20. APHA, Washington, DC, p 4-487

> Azam F, Fenchel T, Field JG, Gray JS, Meyerreil LA, Thingstad F (1983) The ecological role of water-column microbes in the sea. Mar Ecol Prog Ser 10:257-263

Biddanda B, Ogdahl M, Cotner J (2001) Dominance of bacterial metabolism in oligotrophic relative to eutrophic waters. Limnol Oceanogr 46:730-739

Bird DF, Kalff J (1984) Empirical relationships between bacterial abundance and chlorophyll concentration in fresh and marine waters. Can J Fish Aquat Sci 41:1015-1023

Bouvy M, Arfi R, Cecchi P, Corbin D, Pagano M, Saint-Jean L, Thomas S (1998) Trophic coupling between bacterial and phytoplanktonic compartments in shallow tropical reservoirs (Ivory Coast, West Africa). Aquat Microb Ecol 15: 25-37

> Brett M, Lubnow F, Villar-Argaiz M, Müller-Solger A, Goldman C (1999) Nutrient control of bacterioplankton and phytoplankton dynamics. Aquat Ecol 33:135-145

Canosa A, Pinilla G (2007) Relations between bacterioplankton and phytoplankton abundance in three lentic ecosystems in the Colombian Andes. Rev Biol Trop 55:135-146

> Carr GM, Morin A, Chambers PA (2005) Bacteria and algae in stream periphyton along a nutrient gradient. Freshw Biol 50:1337-1350

> Chen W, Wangersky PJ (1996) Rates of microbial degradation of dissolved organic carbon from phytoplankton cultures. J Plankton Res 18:1521-1533

Christoffersen K, Pålsson C, Kritzberg E, Granéli W (2002) Abundance and biomass of microbial communities in relation to phyto:bacterioplankton production in five Faroese lakes. Ann Soc Sci Færoensis (Suppl) 36:59-69

Cole JJ, Findlay S, Pace ML (1988) Bacterial production in fresh and saltwater ecosystems - a cross-system overview. Mar Ecol Prog Ser 43:1-10

Cole JJ, Carpenter SR, Pace ML, Bogert MCV, Kitchell JL, Hodgson JR (2006) Differential support of lake food webs by three types of terrestrial organic carbon. Ecol Lett 9: 558-568

Crisman TL, Beaver JR (1990) Applicability of planktonic biomanipulation for managing eutrophication in the subtropics. Hydrobiologia 200-201:177-185

Currie DJ (1990) Large-scale variability and interactions among phytoplankton, bacterioplankton, and phosphorus. Limnol Oceanogr 35:1437-1455 
del Giorgio PA, Peters RH (1993) The influence of DOC on the bacteria-chlorophyll relationship in lakes. Verh Int Ver Limnol 25:359-362

del Giorgio PA, Peters RH (1994) Patterns in planktonic P:R ratios in lakes: influence of lake trophy and dissolved organic carbon. Limnol Oceanogr 39:772-787

del Giorgio PA, Bird DF, Prairie YT, Planas D (1996) Flow cytometric determination of bacterial abundance in lake plankton with the green nucleic acid stain SYTO 13. Limnol Oceanogr 41:783-789

del Giorgio PA, Cole JJ, Cimbleris A (1997) Respiration rates in bacteria exceed phytoplankton production in unproductive aquatic systems. Nature 385:148-151

Fagerbakke KM, Heldal M, Norland S (1996) Content of carbon, nitrogen, oxygen, sulfur and phosphorus in native aquatic and cultured bacteria. Aquat Microb Ecol 10: $15-27$

Farjalla VF, Amado AM, Suhett AL, Meireles-Pereira F (2009) DOC removal paradigms in highly humic aquatic ecosystems. Environ Sci Pollut Res 16:531-538

Findlay S, Pace ML, Lints D, Cole JJ, Caraco NF, Peierls B (1991) Weak-coupling of bacterial and algal production in a heterotrophic ecosystem: the Hudson River Estuary. Limnol Oceanogr 36:268-278

Fuhrman JA (1999) Marine viruses and their biogeochemical and ecological effects. Nature 399:541-548

> Gao X, Olapade OA, Kershner MW, Leff LG (2004) Algal-bacterial co-variation in streams: a cross-stream comparison. Arch Hydrobiol 159:253-261

- Gasol JM, Duarte CM (2000) Comparative analyses in aquatic microbial ecology: How far do they go? FEMS Microbiol Ecol 31:99-106

Gasol JM, Vaqué D (1993) Lack of coupling between heterotrophic nanoflagellates and bacteria: A general phenomenon across aquatic systems? Limnol Oceanogr 38:657-665

- Gocke K, Hernández C, Giesenhagen H, Hoppe HG (2004) Seasonal variations of bacterial abundance and biomass and their relation to phytoplankton in the hypertrophic tropical lagoon Ciénaga Grande de Santa Marta, Colombia. J Plankton Res 26:1429-1439

Hobbie JE, Daley RJ, Jasper S (1977) Use of Nuclepore filters for counting bacteria by fluorescence microscopy. Appl Environ Microbiol 49:1225-1228

> Huszar VLM, Reynolds CS (1997) Phytoplankton periodicity and sequences of dominance in an Amazonian flood-plain lake (Lago Batata, Pará, Brazil): responses to gradual environmental change. Hydrobiologia 346:169-181

> Jeppesen E, Jensen JP, Søndergaard M, Sortkjær O (1996) Fish-induced changes in zooplankton grazing on phytoplankton and bacterioplankton: a long-term study in shallow hypertrophic Lake Søbygård. J Plankton Res 18: 1605-1625

> Jeppesen E, Erlandsen M, Søndergaard M (1997) Can simple empirical equations describe the seasonal dynamics of bacterioplankton in lakes: an eight-year study in shallow hypertrophic and biologically highly dynamic Lake Søbygård, Denmark. Microb Ecol 34:11-26

> Jeppesen E, Meerhoff M, Jakobsen BA, Hansen RS and others (2007) Restoration of shallow lakes by nutrient control and biomanipulation - the successful strategy depends on lake size and climate. Hydrobiologia 581:269-288

> Jürgens K, Jeppesen E (2000) The impact of metazooplankton on the structure of the microbial food web in a shallow, hypertrophic lake. J Plankton Res 22:1047-1070

Karlsson J, Jansson M, Jonsson A (2002) Similar relationships between pelagic primary and bacterial production in clearwater and humic lakes. Ecology 83:2902-2910
Kritzberg EM, Cole JJ, Pace MM, Granéli W (2005) Does autochthonous primary production drive variability in bacterial metabolism and growth efficiency in lakes dominated by terrestrial $\mathrm{C}$ inputs? Aquat Microb Ecol 38: 103-111

- Lee CW, Bong CW (2008) Bacterial abundance and production, and their relation to primary production in tropical coastal waters of Peninsular Malaysia. Mar Freshw Res 59: $10-21$

Meerhoff MJM, Clemente FTM, Iglesias C, Pedersen AR, Jeppesen E (2007) Can warm climate-related structure of littoral predator assemblages weaken the clear water state in shallow lakes? Glob Change Biol 13:1888-1897

> Nabout JC, Nogueira IS, Oliveira LG (2006) Phytoplankton community of floodplain lakes of the Araguaia River, Brazil, in the rainy and dry seasons. J Plankton Res 28: 181-193

Naganuma T (1997) Abundance and production of bacterioplankton along a transect of Ise Bay, Japan. J Oceanogr 53:579-583

Nürnberg GK (1996) Trophic state of clear and colored, softand hardwater lakes with special consideration of nutrients, anoxia, phytoplankton and fish. Lake Reservoir Manag 12:432-447

Pace ML, McManus GB, Findlay SEG (1990) Planktonic community structure determines the fate of bacterial production in a temperate lake. Limnol Oceanogr 35:795-808

Pirlot S, Unrein F, Descy JP, Servais P (2007) Fate of heterotrophic bacteria in Lake Tanganyika (East Africa). FEMS Microbiol Ecol 62:354-364

Pivato BM, Train S, Rodrigues LC (2006) Dinâmica nictemeral das assembléias fitoplanctônicas em um reservatório tropical (reservatório de Corumbá, Estado de Goiás, Brasil), em dois períodos do ciclo hidrológico. Acta Sci Biol Sci 28: $19-29$

Pomeroy LR (1974) The ocean food web a changing paradigm. Bioscience 24:499-504

Reynolds CS (1995) River plankton: the paradigm regained. In: Harper D, Ferguson AJD (eds) The ecological basis for river management. Wiley, Chichester, p 161-174

Roland F (1998) Produção fitoplanctônica em diferentes classes de tamanho nas Lagoas Imboassica e Cabiúnas. In: Esteves FA (org) Ecologia das lagoas costeiras - do Parque Nacional da Restinga de Jurubatiba e do Município de Macaé (RJ), 1st edn. Editora da Universidade Federal do Rio de Janeiro, p 159-176

$>$ Roland F, Cole JJ (1999) Regulation of bacterial growth efficiency in a large turbid estuary. Aquat Microb Ecol 20: $31-38$

> Sarmento H, Unrein F, Isumbisho MA, Stenuite S, Gasol JM, Descy JP (2008) Abundance and distribution of picoplankton in tropical, oligotrophic Lake Kivu, eastern Africa. Freshw Biol 53:756-771

> Shiah FK, Chen TY, Gong GC, Chen CC, Chiang KP, Hung JJ (2001) Differential coupling of bacterial and primary production in mesotrophic and oligotrophic systems of the East China Sea. Aquat Microb Ecol 23:273-282

Sieburth JM, Lenz VSJ (1978) Pelagic ecosystem structure: heterotrophic compartments of the plankton and their relationship to plankton size fractions. Limnol Oceanogr 23:1256-1263

Simon M, Cho BC, Azam F (1992) Significance of bacterial biomass in lakes and the ocean: comparison to phytoplankton biomass and biogeochemical implications. Mar Ecol Prog Ser 86:103-110

Soares MCS, Huszar VLM, Roland F (2007) Phytoplankton dynamics in two tropical rivers with different degrees of 
human impact (southeast Brazil). River Res Appl 23: 698-714

Søndergaard M, Danielsen M (2001) Active bacteria (CTC+) in temperate lakes: temporal and cross-system variations. J Plankton Res 23:1195-1206

Stenuite S, Pirlot S, Tarbe AL, Sarmento H and others (2009) Abundance and production of bacteria, and relationship to phytoplankton production, in a large tropical lake (Lake Tanganyika). Freshw Biol 54:1300-1311

Stets EG, Cotner JB (2008) The influence of dissolved organic carbon on bacterial phosphorus uptake and bacteriaphytoplankton dynamics in two Minnesota lakes. Limnol Oceanogr 53:137-147

Stewart FJ, Fritsen CH (2004) Bacteria-algae relationships in Antarctic sea ice. Antarct Sci 16:143-156

Tadonléké RD, Pinel-Alloul B, Bourbonnais N, Pick FR (2004) Factors affecting the bacteria-heterotrophic nanoflagel-

Editorial responsibility: Josep Gasol,

Barcelona, Spain late relationship in oligo-mesotrophic lakes. J Plankton Res 26:681-695

Utermöhl H (1958) Zur Vervollkommung der quantitativen Phytoplankton-Methodik. Mitt Inter Ver Limnol 9:1-38

Wetzel RG, Likens GE (2000) Limnological analyses, Book 3. Springer-Verlag, New York, NY

White PA, Kalff J, Rasmussen JB, Gasol JM (1991) The effect of temperature and algal biomass on bacterial production and specific growth-rate in freshwater and marine habitats. Microb Ecol 21:99-118

Zinabu GM, Taylor WD (1997) Bacteria-chlorophyll relationships in Ethiopian lakes of varying salinity: Are soda lakes different? J Plankton Res 19:647-654

Z Zöllner E, Santer B, Boersma M, Hoppe HG, Jürgens K (2003) Cascading predation effects of Daphnia and copepods on microbial food web components. Freshw Biol 48: 2174-2193

Submitted: July 14, 2009; Accepted: May 18, 2010

Proofs received from author(s): July 4, 2010 